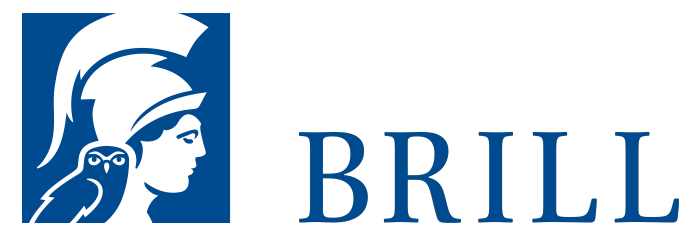

\title{
As Time Goes By
}

\section{Eternal facts in an Ageing Universe}

Authors: Fabrice Correira and Sven Rosenkranz

As Time Goes By offers an overview of different versions of tense realism, or A-theories of time, critically assesses those that have found supporters in the extant literature, and finally explicates and defends a hitherto neglected A-theory of time that combines many of the virtues that the B-theory claims for itself, while avoiding many of the vices that afflict more standard A-theories. Proceeding from certain general assumptions about time and its structure, the authors first provide an exhaustive classification of mutually exclusive realist views of tense in terms of precise criteria. They then critically review the more familiar of these views, such as presentism and relativism, in the light of desiderata any Atheory should satisfy, before showing how their favourite Atheory can satisfy all of these desiderata and how it escapes the McTaggartian trilemma recently expounded by Kit Fine. In the last part, the authors devise a systematic metaphysics for that view, give a reduction of times, and of the temporal order, in its terms, and provide a full semantics, statable exclusively in tensed terms, for both tensed and untensed language. The book closes by addressing and defusing the challenge that the authors' favourite A-theory is a B-theory in disguise.

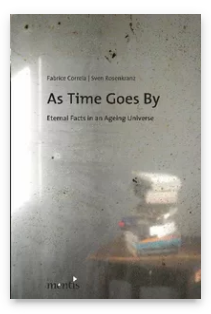

Pages: 132

Seiten

Language:

English

Subjects:

General,

Philosophy

Publisher: Brill | mentis

E-Book (PDF)

Released online: 23 Sep 2011

ISBN: 978-3-

95743-889-8

List price

USD \$40.00

Paperback

Publication date:

23 Sep 2011

ISBN: 978-3-

89785-748-3

List price

USD \$40.00 
For more information see brill.com

Order information: Order online at brill.com +44330 333 0049 | customerservices@brill.com Submission information: brill.com/authors

Titles published by Brill | Fink, Brill | mentis or Brill | Schöningh: +49(o)715413279216| brill@brocom.de 